\title{
Specificity of the Pseudomonas aeruginosa PAO1 lipoprotein I gene as a DNA probe and PCR target region within the Pseudomonadaceae
}

\author{
Alain Saint-Onge, ${ }^{1} \dagger$ Françoise Romeyer, ${ }^{1} \ddagger$ Pierre Lebel, ${ }^{2}$ LUKe Masson ${ }^{1}$ \\ and ROLAND BROUSSEAU ${ }^{*}$ * \\ ${ }^{1}$ Molecular Genetics Section, Biotechnology Research Institute, 6100 Royalmount Avenue, Montreal, Quebec, \\ Canada H4P 2R2 \\ ${ }^{2}$ Department of Microbiology and Immunology, Sainte-Justine Hospital, 3175 Chemin Côte Sainte-Catherine, Montreal, \\ Quebec, Canada H3T 1 C5
}

(Received 10 October 1991; revised 9 January 1992; accepted 17 January 1992)

\begin{abstract}
The lipoprotein I gene (oprI) of Pseudomonas aeruginosa PAO1 was cloned and sequenced. A high degree of homology was found between our cloned PAO1 gene sequence and two published oprI sequences. Specific oligonucleotides were designed to amplify the oprI gene by the polymerase chain reaction (PCR). The potential of either the complete gene sequence or the specific oligonucleotide primers as a tool for rapid strain identification was directly assessed against bacterial colonies by PCR or against purified genomic DNA by Southern blot analysis, using a number of representative strains within the Pseudomonadaceae. The oprI gene was found to be well conserved within RNA group I.
\end{abstract}

\section{Introduction}

There is an increasing interest in techniques for the rapid identification of Pseudomonas species because of their importance in the clinical environment. Pseudomonas species have been identified as the causal agent of many opportunistic infections (Sanford, 1990) and also as the causative agent of corneal ulcers (Reid \& Wood, 1979; Wilson et al., 1981). The currently used identification methods require a variety of biochemical tests, which are sometimes insufficient for the identification of certain species of Pseudomonas, such as various glucose-oxidizing strains, mucoid strains and apyocyanogenic $P$. aeruginosa (Gilardi, 1985). It would therefore be of interest to supplement existing methods with DNA probe and PCR techniques, provided that these are sufficiently accurate and specific.

The first applications of molecular genetic techniques for bacterial taxonomy studies used the techniques of

- Author for correspondence. Tel. (514) 4966152 ; fax (514) 4966232.

+ Present address: Department of Pharmacy, Laval University, Sainte-Foy, Quebec, Canada.

$\ddagger$ Present address: Sandoz-Canada Inc., 385 Boulevard Bouchard, Dorval, Quebec, Canada H9S 1 A9.

The nucleotide sequence data reported in this paper have been submitted to EMBL and have been assigned the accession number X58714. whole genome hybridization (for DNA) and of cataloguing oligonucleotides produced by degradation of rRNA species. These methods form the basis upon which Pseudomonadaceae are classified into five RNA groups containing DNA subgroups (Palleroni, 1984). Although the results obtained are still very useful for taxonomic purposes, the techniques are generally too time-consuming and difficult for clinical application. Also, a given RNA group may bring together species which differ greatly in their pathogenicity toward humans, and human pathogens may be dispersed between several different RNA groups within a family.

The newer DNA hybridization techniques with specific DNA probes have been widely used for the identification of many pathogens (Tenover, 1988); however, these techniques still involve a considerable expense of time and reagents and commonly use radioactive materials. New approaches based on the amplification of a specific genomic DNA target by a thermostable polymerase, the polymerase chain reaction (PCR) (Mullis \& Faloona, 1987), promise to extend the scope of DNA-based methods in terms of rapidity and simplicity. The characteristic amplified DNA fragment can serve for direct identification on gel electrophoresis without the need for radiolabelling.

In this study, we describe the use of a gene coding for an outer-membrane protein (OprI, Hancock et al., 1990) 
of P. aeruginosa PAO1 (Holloway, 1969) to serve both as a DNA probe and as a PCR target for the rapid identification of RNA group I of the Pseudomonadaceae.

\section{Methods}

Bacterial strains, phages and growth conditions. The reference and clinical bacterial strains used in this study are listed in Tables 1 and 2 according to the most recent classification (Gilardi, 1990). The clinical isolates used were obtained from patients of the Sainte-Justine Hospital and identified using standard microbiology laboratory techniques (Gilardi, 1985). Escherichia coli HB101 (supE44 hsdS20 ( $\mathrm{r}_{\bar{B}}^{-} \mathrm{m}_{\bar{B}}$ ) recA13 ara-14 proA2 lacY1 galK2 rpsL20 xyl-5 mtl-1) was used for propagation of the cosmid pLAFR1 (Friedman et al., 1982) and E. coli TG1 (supE hsd $\triangle 5$ thi $\triangle$ (lac-proAB) $\mathrm{F}^{\prime}$ [traD36 proAB+ lacI' lacDM15]) as a host for M13 phages (Yanisch-Perron et al., 1985).

Pseudomonas, Flavimonas, Chryseomonas, Xanthomonas and E. coli strains were grown in 2YT broth (Sambrook et al., 1989). The Streptococcus, Staphylococcus and Branhamella strains were grown in trypticase soy broth $\left(30 \mathrm{~g}^{-1}\right)$ (BBL 11768). The Haemophilus strain

Table 1. Reference bacterial strains used in this study

\begin{tabular}{ll}
\hline \multicolumn{1}{c}{ Strain } & \multicolumn{1}{c}{ Origin* } \\
\hline Pseudomonadaceae & \\
Pseudomonas aeruginosa PAO1 & LSPQ \\
Pseudomonas aeruginosa serotype I to 17 & ATCC 33338 to 33364 \\
Pseudomonas alcaligenes & ATCC 14909 \\
Pseudomonas cepacia & LSPQ and ATCC 25416 \\
Pseudomonas chlororaphis & ATCC 9446 \\
Pseudomonas diminuta & LSPQ and ATCC 11568 \\
Pseudomonas fluorescens & LSPQ and ATCC 13525 \\
Pseudomonas mendocina & ATCC 25411 \\
Pseudomonas paucimobilist & LSPQ and ATCC 29837 \\
Pseudomonas pickettii & LSPQ and ATCC 27511 \\
Pseudomonas pseudoalcaligenes & strain KF707 $\$$ and \\
& ATCC 17440 \\
Pseudomonas putida biotype A & LSPQ and ATCC 12633 \\
Pseudomonas stutzeri & LSPQ and ATCC 17588 \\
Pseudomonas vesicularis & LSPQ and ATCC 11426 \\
Chryseomonas luteola & ATCC 43273 \\
Comamonas acidovorans & LSPQ and ATCC 15668 \\
Comamonas testosteroni\| & LSPQ and ATCC 11996 \\
Flavimonas oryzihabitans & LSPQ and ATCC 43272 \\
Xanthomonas maltophilia & LSPQ and ATCC 13637 \\
Other species & \\
Branhamella catarrhalis & ATCC 25238 \\
Escherichia coli HB101 & Bolivar \& Backman (1979) \\
Haemophilus influenzae & ATCC 33391 \\
Staphylococcus aureus & ATCC 29213 \\
Streptococcus mitis & ATCC 33399 \\
\hline \hline
\end{tabular}

- LSPQ, Laboratoire de Santé Publique du Québec, Sainte-Anne des Plaines, Quebec, Canada; ATCC, American Type Culture Collection, Rockville, MD, USA.

† The transfer of $P$. paucimobilis to a new genus, Sphingomonas, has been proposed (Yabuuchi et al., 1990).

$\ddagger$ Furukawa \& Miyazaki (1986).

\| Tamaoka et al. (1987).

$\S$ Holmes et al. (1987).

II Swings et al. (1983).
Table 2. Clinical isolates used in this study

\begin{tabular}{|c|c|c|}
\hline Isolate* & Origin $†$ & Isolate* \\
\hline $\begin{array}{l}\text { Pseudomona } \\
\text { M/S } 16 \\
\text { M/S } 32 \\
\text { M/S 41 } \\
\text { M/S } 47 \\
\text { M/S } 86 \\
\text { M/S } 96 \\
\text { M/S } 99 \\
\text { M/S } 179 \\
\text { M/S } 190 \\
\text { M/S } 193 \\
\text { M/S } 225 \\
\text { M/S } 240 \\
\text { M/S } 246 \\
\text { M/S } 273 \\
\text { M/S } 280 \\
\text { M/S } 313 \\
\text { M/S } 316\end{array}$ & $\begin{array}{l}\text { as aeruginosa } \\
\text { Expectoration (CFP) } \\
\text { Expectoration } \\
\text { Expectoration } \\
\text { Expectoration (CFP) } \\
\text { Expectoration (CFP) } \\
\text { Neck wound } \\
\text { Expectoration (CFP) } \\
\text { Peritoneum } \\
\text { Pus } \\
\text { Urine } \\
\text { Urine } \\
\text { Expectoration } \\
\text { Faeces } \\
\text { CFP } \\
\text { Urine } \\
\text { Bronchial secretions } \\
\text { (CFP) } \\
\text { Expectoration (CFP) }\end{array}$ & $\begin{array}{l}\text { Pseudomonas cepacia } \\
\text { M/S } 567 \text { Expectoration (CFP) } \\
\text { Pseudomonas putida } \\
\text { M/S } 430 \text { Throat } \\
\text { Pseudomonas stutzeri } \\
\text { M/S } 441 \text { Expectoration (CFP) } \\
\text { Xanthomonas maltophilia } \\
\text { M/S } 426 \text { Endocarditis } \\
\text { M/S } 428 \text { Septicaemia }\end{array}$ \\
\hline
\end{tabular}

- Identification number of clinical isolates from Sainte-Justine hospital.

+ CFP, sample obtained from cystic fibrosis patients.

$\ddagger$ All $P$. aeruginosa isolates had a non-mucoid phenotype.

was grown in brain heart infusion broth with $10 \mathrm{mg}$ haemin $\mathrm{l}^{-1}$. E. coli HB101 containing the cosmid pLAFR1 was grown in the presence of tetracycline at $15 \mathrm{mg} \mathrm{l}^{-1}$ in $2 \mathrm{YT}$ broth.

Cloning and sequencing of the oprI gene. A P. aeruginosa PAO1 genomic DNA library was constructed using the cosmid pLAFR1. Approximately $10^{4}$ clones were screened with sera from cystic fibrosis patients known to have high antibody titres against the outermembrane proteins of $P$. aeruginosa (Hancock et al., 1984). The recombinant clones were transferred to nitrocellulose membranes and incubated with sera which had previously been absorbed against $E$. coli HB101 containing the pLAFR1 cosmid. The bound antibodies were visualized with an alkaline phosphatase biotin-streptavidin detection system (Jackson Immunological). All antibody-positive clones contained a similar $23 \mathrm{~kb}$ fragment as shown by restriction enzyme analysis (data not shown). The positive clones were shown to express a $10 \mathrm{kDa}$ protein by SDS-PAGE, reacting with the cystic fibrosis antibodies by Western blot analysis. This molecular mass corresponded to the Oprl protein as previously reported (Mizuno \& Kageyama, 1979). The $23 \mathrm{~kb}$ insert from one of the positive cosmids was restricted with Pst I and a $2.3 \mathrm{~kb}$ fragment was ligated to Pst I-digested M13mp19 vector. The ligation mixture was then used to transform $E$. coli TGI.

M13 clones were sequenced by the dideoxy chain-termination method (Sanger et al., 1977). Oligonucleotides derived from the recently published sequence of the oprl gene from a clinical isolate of $P$. aeruginosa (Cornelis et al., 1989) were used to identify the appropriate M13 clones and also to sequence the gene. The sequencing reactions were performed as described in the protocol for the T7 Sequencing Kit (Pharmacia) with $\left[\alpha^{35}\right.$ S]dATP. Approximately 350 base pairs were sequenced in both orientations.

Extraction of genomic DNA. The procedure for the extraction of total genomic DNA was based on a sodium perchlorate procedure (Marmur, 1961 ; Tardif, 1985). The following protocol was found to be critical for the subsequent restriction enzyme digestion of the genomic DNA. Cells were grown overnight in $15 \mathrm{ml}$ of appropriate medium, then centrifuged $(6000 \mathrm{~g}$ for $5 \mathrm{~min}$ ) and resuspended in $10 \mathrm{ml} \mathrm{GET} \mathrm{(50} \mathrm{mM-}$ 
glucose, $10 \mathrm{~mm}$-EDTA and $25 \mathrm{~mm}$-Tris/HCl, pH 8) containing $12 \mathrm{~g}$ lysozyme $1^{-1}$. The suspension was divided into four tubes $(2.5 \mathrm{ml})$ and incubated at $37^{\circ} \mathrm{C}$ for $30 \mathrm{~min}$ with agitation (225 r.p.m.). Then $0.5 \mathrm{ml}$ $20 \%(w / v)$ SDS was added and the incubation was continued for $30 \mathrm{~min}$ at the same temperature. A volume of $500 \mu \mathrm{l}$ of $5 \mathrm{M}$-sodium perchlorate was added in five steps $(100 \mu l$ at a time, incubating for 5 min between each addition) to a final concentration of $0.83 \mathrm{M}$. The DNA was extracted with phenol/chloroform $(1: 1, v / v)$, precipitated with an equal volume of ice-cold 2-propanol and recovered by centrifugation at $3000 \mathrm{~g}$ for $10 \mathrm{~min}$. The DNA was redissolved in $10 \mathrm{mM}-\mathrm{Tris} / \mathrm{HCl}$ and 1 mM-EDTA (pH 8.0) and treated with RNAase A $\left(100 \mathrm{mg} \mathrm{l}^{-1}\right)$ for approximately $1 \mathrm{~h}$ at $37^{\circ} \mathrm{C}$. The DNA solution was then extracted with chloroform to remove impurities and stored at $-20^{\circ} \mathrm{C}$.

Agarose gel electrophoresis and Southern blotting. Purified genomic DNA concentrations were estimated visually by loading samples on $0.7 \%$ agarose gel containing ethidium bromide $\left(200 \mu \mathrm{gl}^{-1}\right)$ and examination under UV light after electrophoresis. Approximately equal amounts of genomic DNA $(10 \mu \mathrm{g})$ from each organism were digested overnight with the restriction enzyme BstEII at $60^{\circ} \mathrm{C}$. In order to avoid evaporation the digests were overlaid with paraffin oil. Chromosomal digests and PCR reaction mixtures $(5 \mu \mathrm{l})$ were separated by electrophoresis in $0.7 \%$ and $1.5 \%(\mathrm{w} / \mathrm{v})$ agarose respectively, containing ethidium bromide $\left(200 \mu \mathrm{g}^{-1}\right)$. The DNA was transferred onto nylon membranes (Zeta Probe, Bio-Rad) by vacuum blotting. The steps for the depurination, denaturation, neutralization and transfer were performed as specified by the manufacturer of the vacuum blotting equipment used (LKB 2016 VacuGene, Pharmacia).

PCR amplification. The 25-mer primers used for enzymic amplification were derived from the extremities of the $P$. aeruginosa PAOI sequenced lipoprotein I gene. Restriction enzyme sites (underlined) were built into the primers at their $5^{\prime}$ end to facilitate eventual cloning of the gene in an expression vector. The forward primer had the sequence 5'-ACTCGAATTCATGAACAACGTTCTG-3' and the reverse primer had the sequence 5'-CTGGAAGCTTCTATTACTTGCGGCT-3'. All manipulations were performed using disposable, sterile equipment and wearing gloves to avoid contamination. A medium to large bacterial colony was transferred with a sterile tip or needle into $50 \mu \mathrm{l}$ of sterile distilled water. The samples were boiled for $5 \mathrm{~min}$ and centrifuged $(13000 \mathrm{~g})$ for another $5 \mathrm{~min}$. Thirty-five microlitres of supernatant was added to $5 \mu 110 \times$ PCR buffer $(500 \mathrm{mM}-$ $\mathrm{KCl}, 100 \mathrm{~mm}$-Tris/ $\mathrm{HCl} \mathrm{pH} \mathrm{8.3,15} \mathrm{mM}-\mathrm{MgCl}_{2}$ ), $200 \mu \mathrm{M}$ each of the deoxynucleotides dGTP, TTP, dATP and dCTP (Pharmacia), and $25 \mathrm{pmol}$ each of forward and reverse primer. The samples were boiled for $5 \mathrm{~min}$, quickly centrifuged (10 s), placed on ice, and 2 units of Thermus aquaticus DNA polymerase (Pharmacia) was added. Amplification was performed in a DNA thermal cycler (Perkin Elmer-Cetus). The amplification programme used was as follows: $30 \mathrm{~s}$ at $94^{\circ} \mathrm{C}, 25 \mathrm{~s}$ at $50^{\circ} \mathrm{C}$ and $30 \mathrm{~s}$ at $72^{\circ} \mathrm{C}$ for 25 cycles, followed by a final $10 \mathrm{~min}$ extension time at $72^{\circ} \mathrm{C}$ and chilling at $4^{\circ} \mathrm{C}$.

The PCR fragment used for Southern blot analysis was amplified from the pLAFRl clone under similar conditions $\left(30 \mathrm{~s}\right.$ at $94^{\circ} \mathrm{C}, 30 \mathrm{~s}$ at $50^{\circ} \mathrm{C}, 60 \mathrm{~s}$ at $72^{\circ} \mathrm{C}$ for 30 cycles). After amplification, the reaction mixtures were analysed by electrophoresis on $1.5 \%(w / v)$ agarose gel followed by Southern blotting.

DNA hybridization. Approximately $30 \mathrm{ng}$ of the $275 \mathrm{bp}$ fragment obtained by the amplification reaction described above was labelled with $\left[\alpha-{ }^{32}\right.$ P]dCTP using a multiprime DNA labelling kit (Amersham). Labelled DNA was purified by Sephadex G-25 chromatography. The final specific activity of the probe was calculated to be $3 \times 10^{9}$ c.p.m. $\mathrm{ml}^{-1}$. Zeta Probe blotting membranes (Bio-Rad) were prehybridized, hybridized and washed as described in the manufacturer's instructions. The blots were exposed to X-OMAT film (Eastman Kodak) at $-80^{\circ} \mathrm{C}$ with intensifying screens for $16 \mathrm{~h}$.

\section{Results}

\section{Sequence analysis of the oprI gene from $P$. aeruginosa PAOI}

Fig. 1 shows the sequence found for the oprI gene of PAO1. Minor differences exist between this sequence and the published sequences of the oprI gene of $P$. aeruginosa serotype 6 (Duchêne et al., 1989) and of a $P$. aeruginosa clinical isolate (Cornelis et al., 1989). These differences are as follows: (1) in the $5^{\prime}$ non-coding region, the GGG sequence at position -43 in PAO1 is replaced by GG in the clinical isolate and GGGG in $P$. aeruginosa serotype 6 ; (2) in the $3^{\prime}$ non-coding region, between positions 293 and 299, a sequence of seven Ts is found in PAOl and P. aeruginosa serotype 6 whereas a sequence of six Ts is found in the clinical isolate; (3) at position 267, an extra $C$ is found in the clinical isolate; (4) the only difference found in the coding region between the three cloned oprI genes is a silent mutation at position 195, where the T in PAOl is replaced by a C in the clinical isolate and $P$. aeruginosa serotype 6 .

\section{Distribution of the oprI gene within the Pseudomonadaceae}

Enzymic amplification of the oprI gene. The DNA sequence established for the PAO1 oprI gene was used to define PCR primers, with the goal of implementing a rapid and sensitive identification of $P$. aeruginosa through the PCR technique. A pair of primers was designed to amplify a 275 bp fragment covering the entire coding region of the oprI gene. Through the use of DNA hybridization with an internal oprI oligonucleotide, it was confirmed that the $275 \mathrm{bp}$ fragment amplified from pLAFR 1 corresponded to the oprI gene of PAO1 (data not shown).

The PCR primers were then used to investigate the presence or absence of the oprI sequence within the Pseudomonadaceae. The PCR method was found to work well on DNA recovered by touching an isolated bacterial colony with a sterile toothpick or needle. Results were scored on a plus/minus basis in terms of the appearance of a band of the expected mobility on agarose gel electrophoresis. The nature of the amplified band was always confirmed by Southern hybridization under stringent conditions with a probe derived from PCR amplification of the oprI gene contained in the original pLAFR 1 isolate (data not shown).

Enzymic amplification was performed on LSPQ and ATCC reference strains as listed in Table 1 as well as on the freshly isolated clinical strains shown in Table 2. No differences were found between the LSPQ and ATCC strains. For each PCR test, two samples were used for 


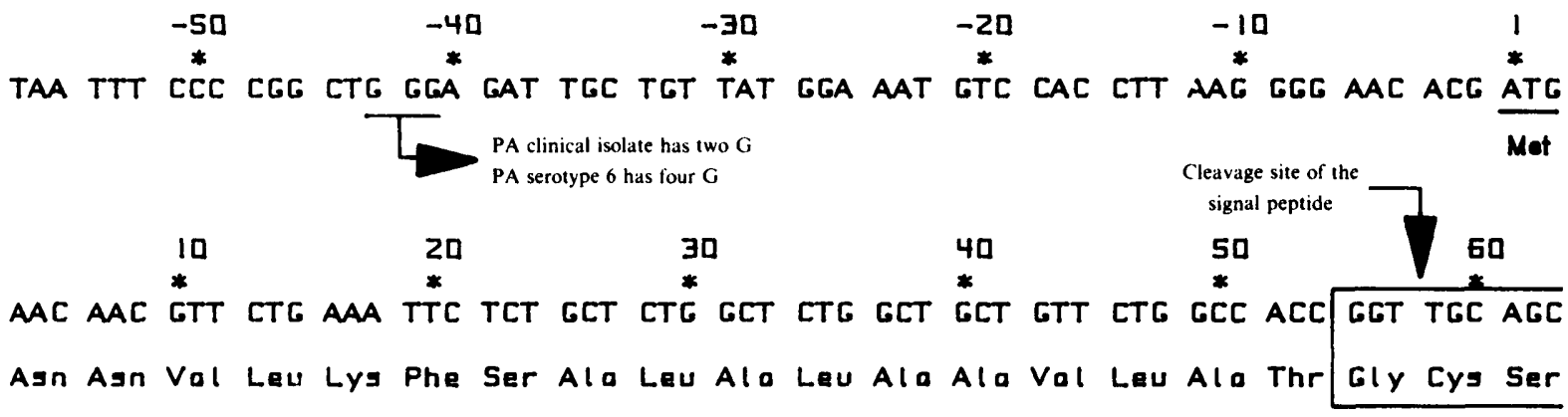

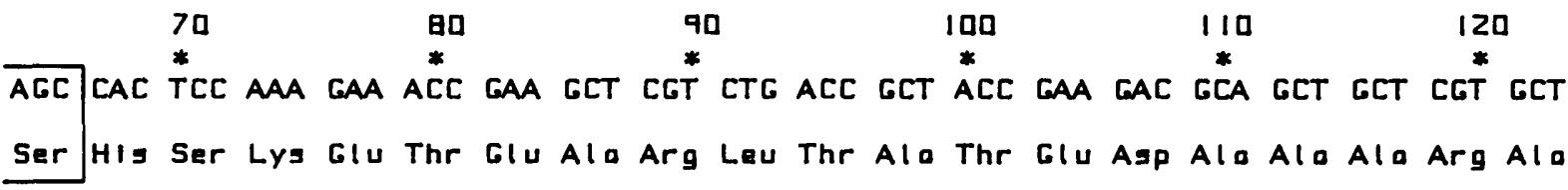

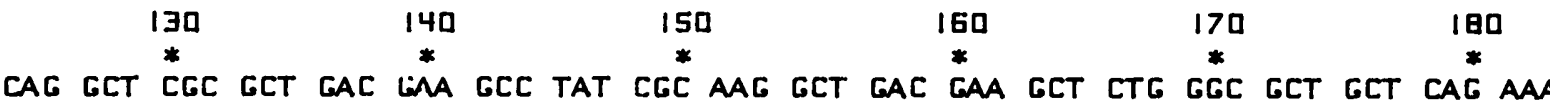
Gin Alo Arg Alo Asp Giu Alo Tyr Arg Lys Ala Agp Glu Ala Lau Gly Ala Ala Gin Lyj

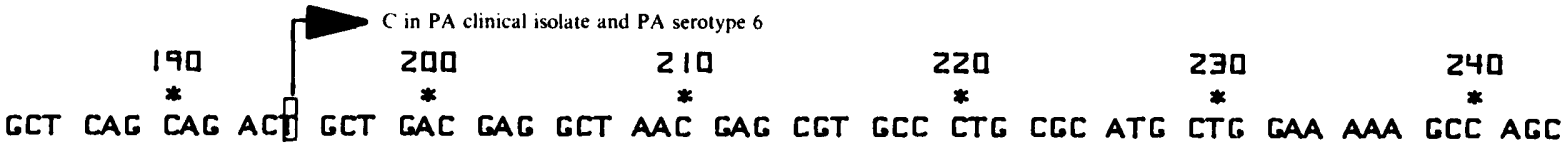
Ala Gin Gin Thr Ala Asp Giu Ala Asn Glu Arg Alo Leu Arg Mat Leu Glu Lys Ala Ser

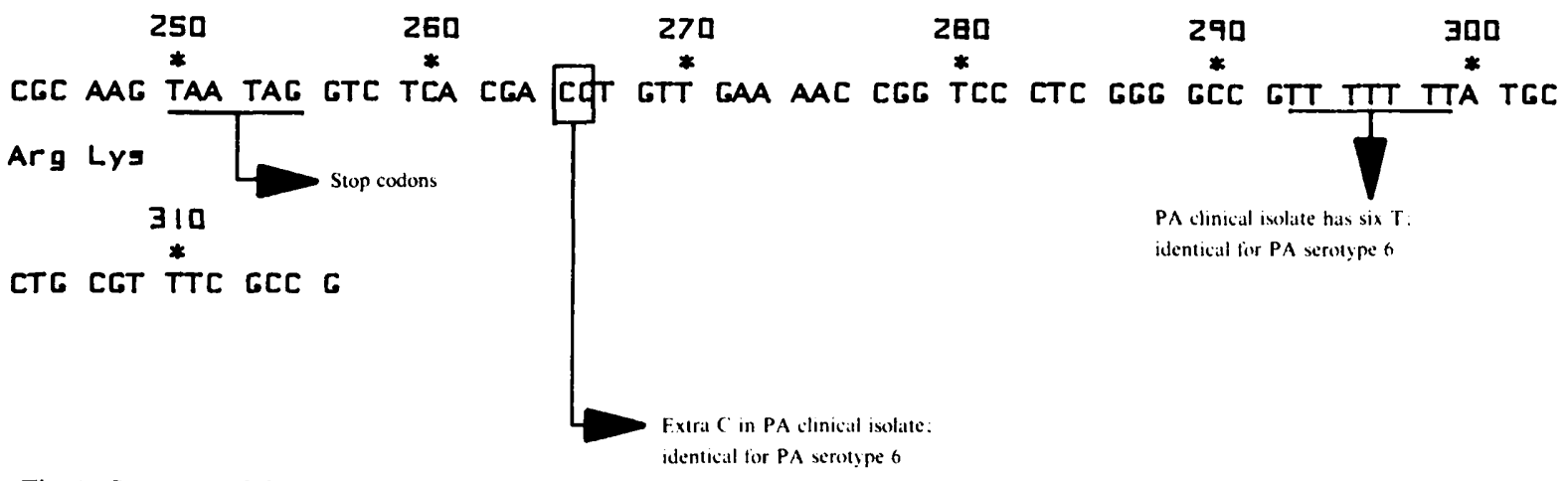

Fig. 1. Sequence of the oprI gene of $P$. aeruginosa PAOl and identification of the differences from two other published sequences. PA clinical isolate : sequence of the oprI gene of $P$. aeruginosa clinical isolate (Cornelis et al., 1989). PA serotype 6: sequence of the oprI gene in $P$. aeruginosa serotype 6 (Duchêne et al., 1989).

negative controls, one containing $E$. coli cells and another containing only dNTP, buffer, primers and enzyme. A positive control of PAO1 was also used for each PCR experiment.

As shown in Table 3, positive results by PCR were found almost entirely within the RNA group $I$ as defined by previous workers (Palleroni, 1984; Gilardi, 1985, 1990). However, under our amplification conditions, strains of two species, $P$. stutzeri and $F$. oryzihabitans, consistently gave weak 275 bp bands, thus they were scored as $+1-$ in the table.
In order to confirm the identity of the amplified fragments, the gels containing the amplified DNA were blotted onto nylon membranes and the latter were hybridized with the entire radiolabelled oprI gene. Positive hybridization was obtained in each case where the PCR result was positive, although $P$. stutzeri and $F$. oryzihabitans showed a weaker signal (data not shown).

Characterization by Southern blottting. Independent validation of the PCR results was obtained through Southern hybridization performed on a genomic DNA prep- 
Table 3. Comparison between PCR and Southern blot results obtained from Pseudomonadaceae and five other species

\begin{tabular}{|c|c|c|c|c|}
\hline Genus & $\begin{array}{l}\text { RNA } \\
\text { group }\end{array}$ & Species & $\begin{array}{l}\text { PCR results confirmed } \\
\text { by hybridization }\end{array}$ & $\begin{array}{c}\text { Genomic DNA } \\
\text { Southern blot results }\end{array}$ \\
\hline \multicolumn{5}{|c|}{ Pseudomonadaceae } \\
\hline Pseudomonas & I & $\begin{array}{l}\text { Pseudomonas aeruginosa } \\
\text { Pseudomonas alcaligenes } \\
\text { Pseudomonas chlororaphis } \\
\text { Pseudomonas fluorescens } \\
\text { Pseudomonas mendocina } \\
\text { Pseudomonas pseudoalcaligenes } \\
\text { Pseudomonas putida biotype A } \\
\text { Pseudomonas stutzeri }\end{array}$ & $\begin{array}{l}+ \\
+ \\
+ \\
+ \\
+ \\
+ \\
+ \\
+1-\end{array}$ & $\begin{array}{l}+ \\
+ \\
+ \\
+ \\
+ \\
+ \\
+ \\
+\end{array}$ \\
\hline & II & $\begin{array}{l}\text { Pseudomonas cepacia } \\
\text { Pseudomonas pickettii }\end{array}$ & - & - \\
\hline & IV & $\begin{array}{l}\text { Pseudomonas diminuta } \\
\text { Pseudomonas vesicularis }\end{array}$ & - & $\overline{-}$ \\
\hline Comamonas & III & $\begin{array}{l}\text { Comamonas acidovorans } \\
\text { Comamonas testosteroni }\end{array}$ & - & $\overline{-}$ \\
\hline Xanthomonas & $\mathbf{v}$ & $\begin{array}{l}\text { Pseudomonas paucimobilis } \\
\text { Xanthomonas maltophilia }\end{array}$ & - & $\begin{array}{l}- \\
-\end{array}$ \\
\hline Chryseomonas & - & Chryseomonas luteola & - & + \\
\hline \multirow[t]{2}{*}{ Flavimonas } & - & Flavimonas oryzihabitans & $+1-$ & + \\
\hline & & $\begin{array}{l}\text { Other spec } \\
\text { Branhamella catarrhalis } \\
\text { Haemophilus influenzae } \\
\text { Streptococcus mitis } \\
\text { Staphylococcus aureus } \\
\text { Escherichia coli } \mathrm{HB} 101\end{array}$ & $\begin{array}{l}- \\
- \\
- \\
-\end{array}$ & $\begin{array}{l}- \\
- \\
- \\
-\end{array}$ \\
\hline
\end{tabular}

aration for each of the strains under study. Genomic DNA was digested with the restriction enzyme BstEII, which allows digestion to be performed at elevated temperature $\left(60^{\circ} \mathrm{C}\right)$; this was found useful for overcoming the poor digestibility of the DNA obtained from some of the strains. The results of this work are shown in Fig. 2 and summarized in Table 3.

Genomic DNA was extracted from LSPQ strains, except when only the ATCC strains were available. The digested genomic DNA was then hybridized with the radiolabelled PCR fragments. Hybridizations were performed with 18 strains of the Pseudomonadaceae and five negative controls. The latter were chosen from pathogenic groups of bacteria representing three Gramnegative species (Branhamella catarrhalis, Haemophilus influenzae and Escherichia coli) and two Gram-positive species (Streptococcus mitis and Staphylococcus aureus). In this study, $P$. aeruginosa $\mathrm{PAO} 1$ and $E$. coli $\mathrm{HB} 101$ were used as positive and negative controls, respectively.

As shown in Fig. 2, positive hybridizations were found for $\boldsymbol{P}$. aeruginosa, $\boldsymbol{P}$. alcaligenes, $\boldsymbol{P}$. chlororaphis, $\boldsymbol{P}$. fluorescens, $P$. mendocina, $P$. pseudoalcaligenes, $P$. putida, $P$. stutzeri, $C$. luteola and $F$. oryzihabitans. All bands had similar intensity, except $F$. oryzihabitans (marked with an arrow in Fig. 2 ), which had a lower genomic DNA concentration on the gel. Only one band of the chromosomal BstEII digestion was found to hybridize with the radiolabelled PCR fragments. No fragments corresponding to the oprI gene were found in $P$. cepacia, $P$. pickettii, $P$. diminuta, $P$. vesicularis, $P$. paucimobilis, $X$. maltophilia, $C$. testosteroni, $C$. acidovorans and in the five other strains not belonging to the Pseudomonadaceae.

\section{Analysis of $P$. aeruginosa serotypes and clinical strains}

PCR amplification was also performed on representative strains of the 17 existing serotype groups, based on the major heat-stable somatic $\mathbf{O}$ antigens found in the International Antigenic Typing System (Liu et al., 1983); the results are shown in Fig. 3. All serotypes showed a distinct band of 275 bp by agarose gel electrophoresis, indicating the presence of the oprI gene.

PCR results were also obtained on 22 clinical isolates from Sainte-Justine Hospital; these are summarized in Table 4. Agreement between conventional microbiological techniques and PCR was found for 19 of these strains (Table 4). Two $P$. aeruginosa isolates and a $P$. putida isolate repeatedly failed to show the predicted result by PCR. These three clinical isolates were non-mucoid, therefore the hypothesis that the DNA is not sufficiently 

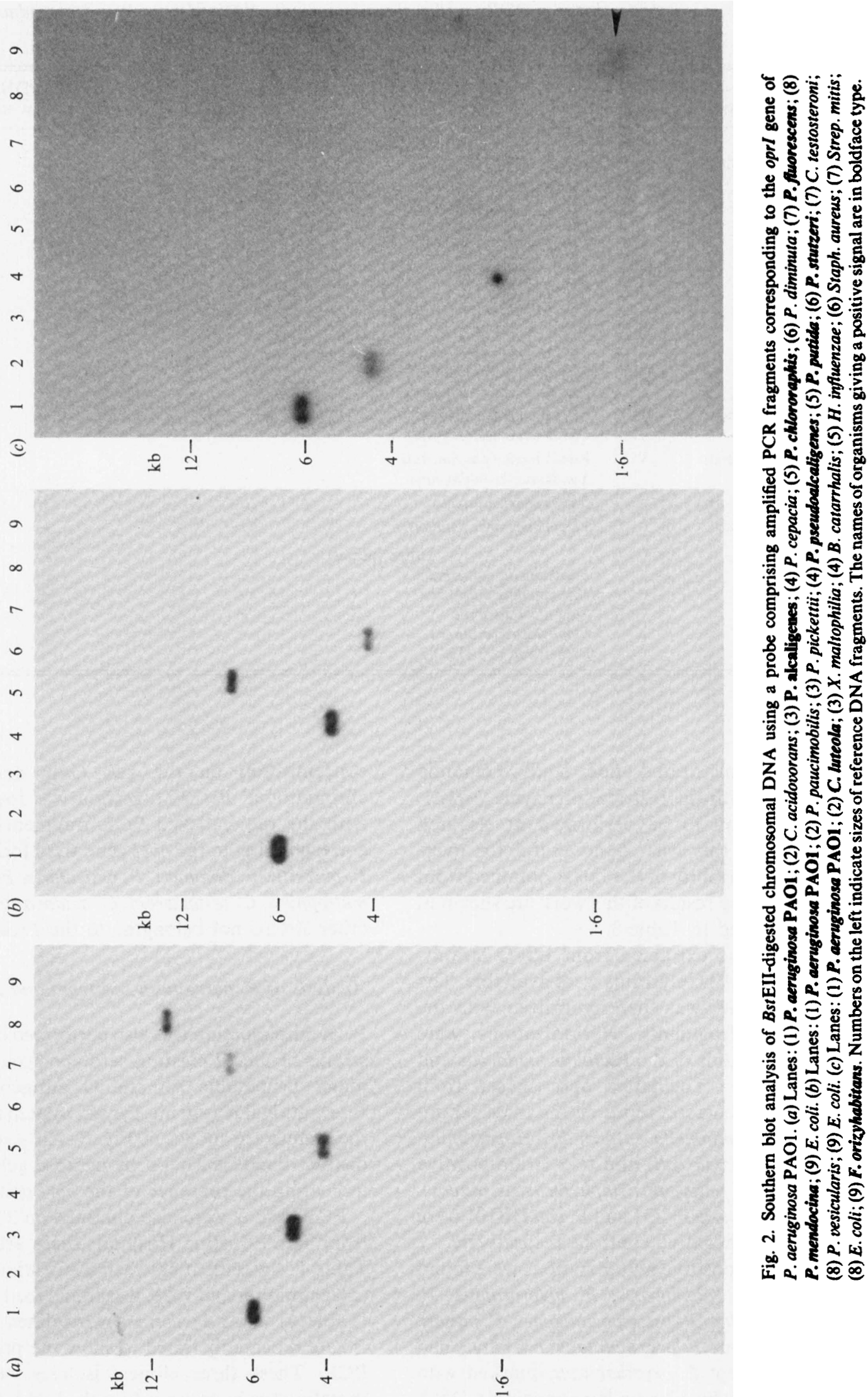

象事定 全金舟

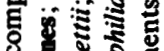

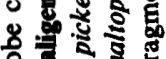
웅 \% त्र

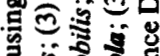
乙 온 西

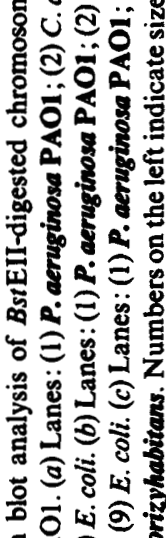

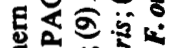

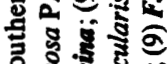
के क्षे N की 


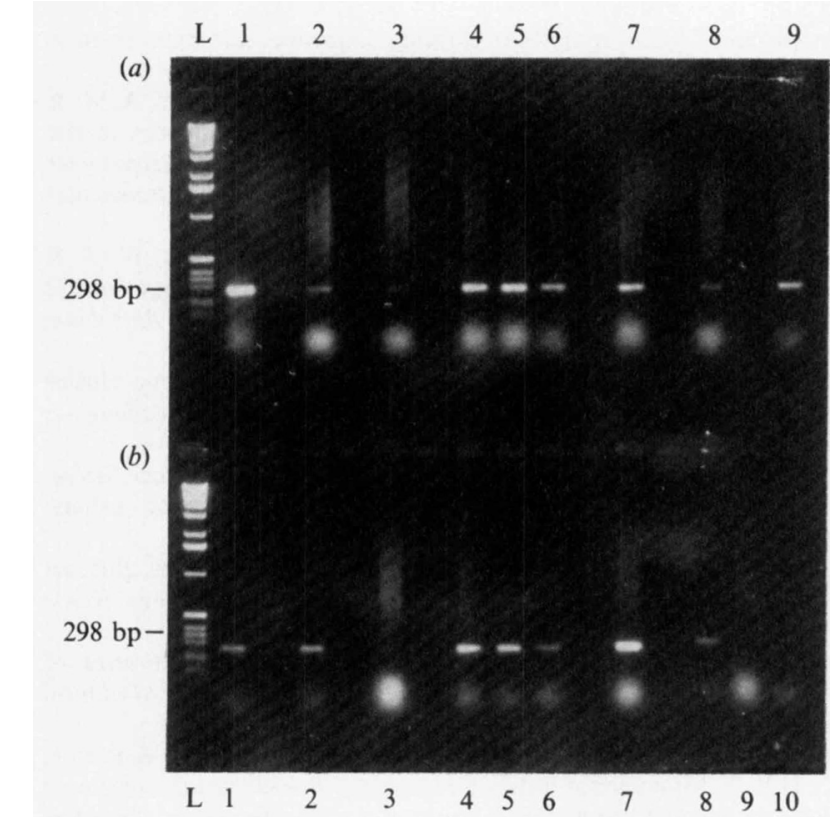

Fig. 3. Amplification of $P$. aeruginosa chromosomal DNA target sequence from 17 serotypes of the International Antigenic Typing System. The PCR method was performed with DNA recovered from isolated colonies resuspended in water and boiled for $5 \mathrm{~min}$. Lane 1 , (a) serotype 1, (b) serotype 10; lane 2, (a) serotype 2, (b) serotype 11; lane 3, (a) serotype 3, (b) serotype 12 ; lane 4, (a) serotype 4, (b) serotype 13; lane 5, (a) serotype 5, (b) serotype 14; lane 6, (a) serotype 6, (b) serotype 15; lane $7,(a)$ serotype $7,(b)$ serotype 16; lane 8, (a) serotype 8, (b) serotype 17; lane 9, (a) serotype 9, (b) E. coli; lane 10, (b) no target. L, $1 \mathrm{~kb}$ ladder. The number on the left indicates the length of the standard closest to the fragment amplified.

Table 4. PCR results obtained on different clinical isolates

\begin{tabular}{|c|c|c|}
\hline Isolate & $\begin{array}{l}\text { Presence of } \\
\text { oprI gene }\end{array}$ & $\begin{array}{l}\text { Presence of } \\
\text { oprI gene }\end{array}$ \\
\hline \multicolumn{2}{|c|}{ Pseudomonas aeruginosa } & \\
\hline $\mathrm{M} / \mathrm{S} 16$ & + & M/S 567 \\
\hline $\mathrm{M} / \mathrm{S} 32$ & - & Pseudomonas putida \\
\hline M/S 41 & + & $\mathrm{M} / \mathrm{S} 430$ \\
\hline M/S 47 & + & Pseudomonas stutzeri \\
\hline M/S 86 & + & M/S 441 \\
\hline M/S 96 & + & Xanthomonas maltophilia \\
\hline M/S 99 & + & M/S 426 \\
\hline $\mathrm{M} / \mathrm{S} 179$ & - & $\mathrm{M} / \mathrm{S} 428$ \\
\hline $\mathrm{M} / \mathrm{S} 190$ & + & \\
\hline M/S 193 & + & \\
\hline M/S 225 & + & \\
\hline M/S 240 & + & \\
\hline M/S 246 & + & \\
\hline M/S 273 & + & \\
\hline M/S 280 & + & \\
\hline M/S 313 & + & \\
\hline M/S 316 & + & \\
\hline
\end{tabular}

released by the boiling treatment is not thought to be pertinent in this case. Repeating the microbiological identification of these three isolates confirmed the original assignment. The microbiological techniques used were verified using the LSPQ reference strains; all strains were correctly identified. Therefore the hypothesis that the oprI gene can be absent from an otherwise phenotypically normal strain, as determined by culture methods, will need to be explored in subsequent work.

\section{Discussion}

The Opr proteins of Pseudomonas (reviewed by Hancock et al., 1990) offer interesting characteristics for the development of DNA probes. Previous work at the protein and immunological levels has shown that these proteins are strongly conserved within the 17 serotypes of $P$. aeruginosa as well as within different clinical and environmental isolates (Hancock et al., 1982; Mutharia \& Hancock, 1985; Hancock \& Chan, 1988). More recent publications (reviewed in Hancock et al., 1990) confirm this conserved character through molecular genetic techniques.

The work presented here agrees with the previously published protein, immunological and genetic results. The DNA sequence determined for oprI of $P$. aeruginosa PAO1 is very close, though not identical, to those previously published for a clinical isolate (Cornelis et al., 1989) and for $P$. aeruginosa serotype 6 (Duchêne et al., 1989). The predicted protein sequence is identical, as might be expected from the protein electrophoresis and immunological data (Mutharia et al., 1982). On the other hand, the fact that the DNA sequence differs, even if very slightly, indicates that caution must be used in assuming that a PCR primer derived from the sequence of a given isolate will exactly match other isolates.

Taken together, the Southern blot results and PCR results demonstrate that the oprI gene is found primarily within organisms of RNA group I. This result is consistent with previous studies. Fialho et al. (1990) reported that the four alg (alginate-producing) genes were conserved within RNA group I. Recent work (Siehnel et al., 1990) on the oprP gene found this gene well conserved within RNA group I but absent in representatives of the other RNA groups. These results, when combined with the present findings that the oprI genes are conserved within RNA group I but not commonly found outside it, strengthen the view of group I as a homogeneous entity at the DNA, rRNA and protein levels. It will be of interest, in the light of the results found in this work for $C$. luteola and $F$. oryzihabitans, whether other indications will be found to reclassify these organisms as part of RNA group I.

The PCR results are also satisfactory within the $P$. aeruginosa serotypes inasmuch as all serotypes gave a positive signal. This was to be expected in view of previous work (Mutharia et al., 1982) showing a high 
degree of conservation of the outer-membrane proteins amongst the $P$. aeruginosa serotypes. Our PCR results on clinical isolates, where we found the oprI gene in most but not all (19/22) of the isolates examined, are also in line with previously published results. For instance, using a monoclonal antibody against $\mathrm{OprH} 2,50$ out of 52 strains of $P$. aeruginosa tested were positive (Mutharia \& Hancock, 1985).

The easily and rapidly obtained PCR results correlated strongly with the more labour-intensive Southernblotting method. In the one case where the result was different, the contrast between the positive Southern hybridation result with $C$. luteola and its consistently negative PCR result is probably explained by sequence divergence at one of the sites for the PCR primers. The same hypothesis may also explain the weaker PCR signals consistently obtained for $P$. stutzeri and $F$. oryzihabitans. All other species tested gave the same result whether by PCR or Southern blot.

Sample preparation for the PCR method (harvesting a single colony followed by boiling and centrifugation) is sufficiently simple and easy that it can be readily performed in clinical or environmental laboratories. The avoidance of radiolabelling is also a significant advantage for such laboratories.

The present study has established oprI as a generally applicable PCR target region and DNA probe within RNA group I of the Pseudomonadaceae. It has also provided evidence suggesting that $C$. luteola and $F$. oryzihabitans may be related to RNA group I. Probes based on oprI may therefore prove to be of value as taxonomic tools within the Pseudomonadaceae. The use of oprI as a PCR target site may find applications in other areas such as the testing of pharmaceutical preparations, in particular, ophthalmic solutions and eye cosmetics (Reid \& Wood, 1979). In this type of work, where tolerance for bacterial contamination is essentially zero, the rapidity and the great sensitivity of the method would provide added insurance against low-level contamination by any member of RNA group I of the Pseudomonadaceae.

This work was supported financially by the 'Fonds pour la formation de chercheurs et l'aide à la recherche' (FCAR) of the Gouvernement du Québec. The support of Dr Thalia Nicas in the early stages of the work is gratefully acknowledged.

\section{References}

Bolivar, F. \& Backman, K. (1979). Plasmids of Escherichia coli as cloning vectors. Methods in Enzymology 68, 245-268.

Cornelis, P., Bouta, A., Belarbi, A., GuYonvarch, A., Kammerer, B., HANNABRT, V. \& HuBERT, J. C. (1989). Cloning and analysis of the gene for the major outer membrane lipoprotein from Pseudomonas aeruginosa. Molecular Microbiology 3, 421-428.

DUChÊNe, M., BArron, C., SCHWEIZER, A., VON SPECht, B. U. \& DOMDEY, H. (1989). Pseudomonas aeruginosa outer membrane lipoprotein I gene: molecular cloning, sequence, and expression in Escherichia coli. Journal of Bacteriology 171, 4130-4137.

Fialho, A. M., Ziblinski, N. A., FetT, W. F., Chakrabarty, A. M. \& BERRY, A. (1990). Distribution of alginate gene sequences in the Pseudomonas rRNA homology group I-Azomonas-Azotobacter lineage of Superfamily B procaryotes. Applied and Environmental Microbiology 56, 436-443.

Friedman, A. M., Long, S. R., Brown, S. E., BuIrema, W. J. \& Ausuber, F. M. (1982). Construction of a broad host range cosmid cloning vector and its use in the genetic analysis of Rhizobium mutants. Gene 18, 289-296.

FurukAWA, K. \& MrYazaki, T. (1986). Cloning of a gene cluster encoding biphenyl and chlorobiphenyl degradation in Pseudomonas pseudoalcaligenes. Journal of Bacteriology 166, 392-398.

GILARDI, G. L. (1985). Pseudomonas. In Manual of Clinical Microbiology, pp. 350-373. Edited by E. H. Lennette and others. Washington, DC: American Society for Microbiology.

GILARDI, G. L. (1990). Update on taxonomy of nonfastidious, glucosenonfermenting gram-negative bacilli. Clinical Microbiology Newsletter 12, 73-76.

HANCOCK, R. E. W. \& CHAN, L. (1988). Outer membranes of environmental isolates of Pseudomonas aeruginosa. Journal of Clinical Microbiology 26, 2423-2424.

HanCoCk, R. E. W., Wieczorex, A. A., Mutharia, L. M. \& Poole, K. (1982). Monoclonal antibodies against Pseudomonas aeruginosa outer membrane antigens: isolation and characterization. Infection and Immunity 37, 166-171.

Hancock, R. E. W., Mouat, E. C. A. \& Speert, D. P. (1984). Quantitation and identification of antibodies to outer-membrane proteins of Pseudomonas aeruginosa in sera of patients with cystic fibrosis. Journal of Infectious Diseases 149, 220-226.

Hancock, R. E. W., Siehnel, R. \& Martin, N. (1990). Outer membrane proteins of Pseudomonas. Molecular Microbiology 4, 1069-1075.

Holloway, B. W. (1969). Genetics of Pseudomonas. Bacteriological Reviews 33, 419-443.

Holmes, B., Steigerwalt, A. G., Weaver, R. E. \& Brenner, D. J. (1987). Chryseomonas luteola comb. nov. and Flavimonas oryzihabitans gen. nov., comb. nov., Pseudomonas-like species from human clinical specimens and formerly known, respectively, as groups Ve-1 and Ve-2. International Journal of Systematic Bacteriology 37, 245-250.

LiU, P. V., MATsumoto, H., Kusama, H. \& Bergan, T. (1983). Survey of heat-stable, major somatic antigens of Pseudomonas aeruginosa. International Journal of Systematic Bacteriology 33, 256-264.

MARMUR, J. (1961). A procedure for the isolation of deoxyribonucleic acid from micro-organisms. Journal of Molecular Biology 3, 208218.

MizUNO, T. \& KAGEYAMA, M. (1979). Isolation and characterization of a major outer membrane protein of Pseudomonas aeruginosa. Journal of Biochemistry 85, 115-122.

Mullis, K. B. \& Faloona, F. A. (1987). Specific synthesis of DNA in vitro via a polymerase catalyzed chain reaction. Methods in Enzymology 155, 335-350.

MUthaRIA, L. M. \& HANCOCK, R. E. W. (1985). Monoclonal antibody for an outer membrane lipoprotein of the Pseudomonas fluorescens group of the family Pseudomonadaceae. International Journal of Systematic Bacteriology 35, 530-532.

MUthaRIA, L. M., Nicas, T. I. \& HANCOCK, R. E. W. (1982). Outer membrane proteins of Pseudomonas aeruginosa serotype strains. Journal of Infectious Diseases 146, 770-779.

Palleron, N. J. (1984). Genus I Pseudomonas Migula. In Bergey's Manual of Systematic Bacteriology, vol. 1, pp. 141-199. Edited by N. R. Krieg \& J. G. Holt. Baltimore: Williams \& Wilkins.

REID, F. R. \& WoOD, T. O. (1979). Pseudomonas corneal ulcer. The causative role of contaminated eye cosmetics. Archives of Ophthalmology 97, 1640.

SAMbroOK, J., Fritsch, E. F. \& Maniatis, T. (1989). Molecular Cloning: a Laboratory Mamual. Cold Spring Harbor, NY: Cold Spring Harbor Laboratory.

SANFord, J. P. (1990). Pseudomonas species. In Principles and Practice of Infectious Diseases, 3rd edn, pp. 1692-1695. Edited by G. L. 
Mandell, R. G. Douglas \& J. E. Bennett. New York: Churchill Livingstone.

SANGer, F., Nicklen, F. \& Coulson, A. R. (1977). DNA sequencing with chain-terminating inhibitors. Proceedings of the National Academy of Sciences of the United States of America 74, 54635467.

Sizhnel, R., Martin, N. L. \& HanCoCK, R. E. W. (1990). Sequence and relatedness in other bacteria of the Pseudomonas aeruginosa opr $P$ gene coding for the phosphate-specific porin P. Molecular Microbiology 4, 831-838.

Swings, J., De Vos, P., Van den Mooter, M. \& De Ley, J. (1983). Transfer of Pseudomonas maltophilia Hugh 1981 to the genus Xanthomonas as Xanthomonas maltophilia (Hugh 1981) comb. nov. International Journal of Systematic Bacteriology 33, 409-413.

TAMAOKA, J., HA, D.-M. \& KomaGATA, K. (1987). Reclassification of Pseudomonas acidovorans den Dooren de Jong 1926 and Pseudomonas testosteroni Marcus and Talaley 1956 as Comamonas acidovorans comb. nov. and Comamonas testosteroni comb. nov., with an emended description of the genus Comamonas. International Journal of Systematic Bacteriology 37, 52-59.

TARDIF, G. (1985). Transfer and behaviour of Inc-N plasmid into Pseudomonas aeruginosa. PhD thesis, University of Toronto.

Tenover, F. C. (1988). Diagnostic deoxyribonucleic acid probes for infectious diseases. Clinical Microbiology Reviews 1, 82-101.

Wilson, L. A., Schlitzer, R. L. \& AhEARN, D. G. (1981). Pseudomonas corneal ulcers associated with soft contact-lens wear. American Journal of Ophthalmology 92, 546-554.

YabuUchi, E., Yano, I., Oyalzu, H., Hashimoto, Y., Ezaki, T. \& Yamamoto, H. (1990). Proposals of Sphingomonas paucimobilis gen. nov. and comb. nov., Sphingomonas parapaucimobilis sp. nov., Sphingomonas yanoikuyae sp. nov., Sphingomonas adhaesiva sp. nov., Sphingomonas capsulata comb. nov., and two genospecies of the genus Sphingomonas. Microbiology and Immunology 34, 99-119.

Yanisch-Perron, C., Vieira, J. \& Messing, J. (1985). Improved M13 phage cloning vectors and host strains: nucleotide sequences of the M13mp18 and pUC19 vectors. Gene 33, 103-119. 